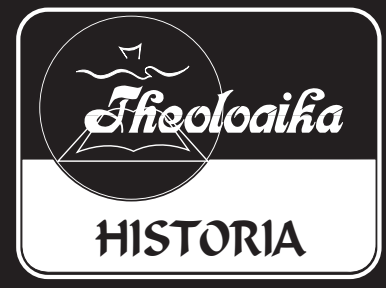

\title{
La influencia de la Biblia en la historia del Perú
}




\section{RESUMEN}

"La influencia de la Biblia en la historia del Perú" - La influencia de la Biblia sobre algunos pueblos de Europa y otros países es notable por su impacto en la sociedad y la edificación de su población. La llegada de la Biblia al Perú no fue grata ni promocionada, sino secreta y perseguida. Su arribo en los días de la Contrarreforma fue amenazante y controvertida. Por un lado estaban los que precisaban de ella para su tarea evangelizadora y por otro lado estaban los esbirros de la Inquisición que la prohibían a toda costa y con la crueldad de la hoguera a los que la poseían y enseñaban. Pese a ellos la Biblia y su mensaje evangélico se abrió paso y hoy el Perú disfruta libremente de la influencia del mensaje de libertad que sólo la Biblia puede dar como Palabra de Dios.

\section{SUMMARY}

"The Influence of the Bible in the History of Peru" - The influence of the Bible is notable in some European countries and other peoples for its impact on the society and the edification of its population. The arrival of the Bible in Peru was neither appreciated nor promoted but secret and persecuted. Its coming during the Counter-Reformation days was menacing and controversial. On one side were those who required it for their evangelistic task and on the other side were the Inquisition's henchmen who prohibited it by any means and with the cruelty of burning at the stake, those who had and taught the Bible. However, in spite of them the Bible and its evangelistic message forced its way in and now Peru freely enjoys the influence of the message of freedom that only the Bible can give as God's word. 


\section{LA INFLUENCIA DE LA BIBLIA EN LA HISTORIA DEL PERÚ}

El siglo XVI fue la época de un nuevo amanecer tanto para Europa como para el Nuevo Mundo. El continente europeo fue sacudido por la Reforma con su grito "Sola fide, sola Scriptura", en tanto que el continente americano al ser "descubierto" comenzó a sufrir una etapa del colonialismo denigrante del cual sólo pudo sacudirse tras cruentos siglos de esclavitud y barbarie. Pero, tanto en Europa como en América, la liberación del oscurantismo y colonialismo sólo fue gracias a la influencia directa del mensaje liberador de la Biblia. Por algo el autor de la libertad, quien se proclama "Yo soy la verdad y la vida" (Juan 14:6), sostiene en las páginas bíblicas la gran verdad irrefutable, "y conoceréis la verdad y la verdad os hará libres" (Juan 8:32).

A tan sólo 15 años de la publicación de las Noventa y cinco tesis contra las indulgencias de Lutero, que fue el punto de partida de la Reforma en Europa, España empieza su presencia en el Perú con un inicio de recuerdo nada grato para la Biblia y sus seguidores.

El año de 1532 es la fecha de la llegada de la Biblia al Perú. El imperio Azteca había sucumbido en 1521 ante el embate de la conquista española dirigida por Hernán Cortés y en México se unieron tres aventureros para iniciar su proyecto invasor del Tawantinsuyo, liderado por Francisco Pizarro. Tras su llegada a Tumbes y su marcha por la costa dejando un reguero 
de traición, sangre y destrucción entre los Tallanes; los expedicionarios llegaron a Cajamarca donde se encontraba el inca con toda su comitiva de nobles y se pactó un encuentro pacífico sin armas.

Sin embargo, la tarde del 16 de noviembre de 1532 el fraile Vicente Valverde, uno de los tres socios, se encargó de presentar la Biblia al monarca incaico en el "encuentro" que devino en una de las más execrables matanzas a traición. Sin ningún saludo amistoso o protocolar de preludio, Valverde procedió a recitar sus exigencias requeridas de grado o de fuerza, en tanto que Atahualpa, percibiendo ya las intenciones de los visitantes, reclamó lo hecho en su reino y exigió de inmediato la devolución de todo lo usurpado. Aquel fue un diálogo tenso, cargado de desconcierto, odio, exigencias inaceptables por ambas partes, pleno de incomprensiones. ${ }^{1}$ En realidad, ¿qué precisiones podía haber transmitido el traductor improvisado de los españoles? Así que finalmente la entrega del libro santo al monarca, quien no conocía y menos sabía "ni la a" de él, fue de sorpresa, y tras hojearlo con verdadera curiosidad, finalmente se lo puso al oído, tratando de darle sentido a lo que se le estaba diciendo de él; probablemente lo consideró como una tomada de pelo o

${ }^{1}$ Antes de perpetrar la matanza, el fraile Valverde recitó a Atahualpa el largo "Requerimiento" en el que ofrecía al Inca la fementida "paz y amistad ... de grado o de fuerza" y le exigió dar obediencia al Papa Sumo Pontífice, y recibir la fe de Cristo nuestro Dios. Y luego le conminó "quieras o no recibas nuestra fe católica" pues de lo contrario él y todos sus indios serían destruidos por las armas. Acto seguido instó a Pizarro a salir de su escondite y a atacar gritando: "Salid de él que yo os absuelvo". Véase Virgilio Roel Pineda, Cultura Peruana e Historia de los Incas (Lima: CARTOLAN, 2001), 543-548. 
como algo inconcebible y hasta insultante de modo que chasqueado y disgustado lo arrojó al suelo.

El libro entregado a Atahualpa en dicha ocasión ha sido motivo de debate pues para unos, como Guamán Poma de Ayala, fue un breviario, ${ }^{2}$ en tanto que para otros, como Garcilaso de la Vega, un libro teológico. ${ }^{3}$ Éstos, sin embargo, escribieron mucho después de ocurrido el hecho, por lo tanto, sus versiones están al menos alejadas del momento y también del verdadero detalle de lo sucedido. Rostworowski menciona que Valverde avanzó hacia el inca con una cruz entre manos y tras exigirle, mediante el "traductor", abrazar la fe católica y servir al rey de España le entregó "el evangelio". ${ }^{4}$

Conviene mencionar que el cronista Cristóbal de Mena quien presenció el suceso esa tarde trágica asevera que el fraile se acercó al inca mostrándole "una cruz" y "un libro de la santa ley". ${ }^{5}$ Además, Francisco de Xerez, quien era el notario público de Francisco Pizarro

${ }^{2}$ Felipe Guamán Poma de Ayala escribiendo e ilustrando el momento un siglo después del incidente, en 1613, refiere que Valverde fue al encuentro del inca "lleuando en la mano derecha una crus y en la esquierda el bribario", John V. Murra y Rolena Adorno, eds., Nueva crónica y buen gobierno (México: Siglo Veintiuno, 1980), 357.

${ }^{3}$ Garcilaso de la Vega escribiendo a dos siglos del hecho, más como apologista de los conquistadores, alega que la Biblia presentada por Valverde "fue la Summa de Santo Tomás", Véase Ángel Rosenblat, ed., Historia General del Perú (Buenos Aires: Editorial Emece, 1943), 1:63, 73.

${ }^{4}$ María Rostworowski de Diez Canseco, Historia del Tawantinsuyo (Lima: Instituto de Estudios Peruanos, 1988), 173.

${ }^{5}$ Ver La Conquista del Perú. Edición facsímile hecha por Jospeh H. Sinclair (New York: New York Public Library, 1929). La primera edición fue publicada en Sevilla en febrero de 1534, a sólo dos años del asesinato de Atahualpa. 
en la expedición al imperio incaico, asevera que el libro mostrado al inca fue la Biblia. ${ }^{6}$ Por otro lado, a menos de treinta años del evento Tito Cusi Yupanqui, en 1570, quien es el primer cronista autóctono, registra que lo dado al inca fue "una carta, un libro, la quillca de Dios, el escrito de Dios".

Lo que siguió es aun más execrable. Atahualpa fue hecho prisionero de Francisco Pizarro quien dispuso el ajusticiamiento del Inca proponiéndole un chantaje religioso a fin de evitarle las penas del infierno, pero no de la tragedia del garrote.

Indudablemente, Atahualpa partió el 16 de julio de 1533 "al más allá" intrigado con una incógnita insoluble, "vaya cristianismo este, traidor, ladrón, codicioso, mentiroso, chantajista, intolerante y bribón. Es tan esclavizante y sanguinario como el wiracochismo o el pachacamismo o el intiismo o el mismo Aipec degollador de los Mochicas en mi incanato. ¿Será ése el mensaje, de esa cosa que éstos le llaman los evangelios y que no alcanzo a escucharlo por más que lo pegue a mis oídos? ¿Qué clase de 'apu' es ése que no honra su palabra y que desde una cruz sólo exige siniestra avaricia?" 8

${ }^{6}$ Ver Francisco de Xerez, Verdadera relación de la conquista del Perú, publicada en junio de 1534, reeditada en la serie Historia 16 (Madrid, 1985), 111.

${ }^{7}$ Instrucción del Inga Don Diego de Castro Titu Cusi Yupanqui para el muy ilustre Señor el Licenciado Lope Garçia de Castro. Governador destos Reynos del Piru. Introducción por Luis Millones (Lima: Ediciones Virrey, 1985), 2. Citado por William Mitchel, La Biblia en la historia del Perú (Lima: Sociedad Bíblica Peruana, 2008), 8 .

${ }^{8}$ Merling Alomía, “Origen y trayectoria histórica de la libertad religiosa en el Perú", conferencia presentada en el Congreso Internacional de Libertad Religiosa - "Un instrumento de Paz", realizado del 28 al 30 de noviembre del 2001, en el Pardo Double Tree Hotel, Miraflores-Lima. 
De hecho la intolerancia religiosa del medioevo practicada en Europa y sancionada por Trento en su campaña de contrarreforma se instaló con igual saña en la Nueva España y, en el Perú, los peruanos conquistados escucharon por siglos las "buenas nuevas" de la conversión por la espada que los obligaba a servir al crucificado so peligro de ser extirpados por un cristianismo conquistador intolerante.

Tal vez la prueba documentada más palpable del impacto producido por el "evangelio del conquistador" en la población peruana sea la dada por el cronista ayacuchano Felipe Guamán Poma de Ayala, que vivió entre los años 1534 y 1615. Evidentemente, él fue un lector asiduo de la Biblia. ${ }^{9}$ Su interpretación histórica y bíblica es singular y muestra de manera real que el impacto bíblico en la sociedad andina fue inmenso pero al mismo tiempo contradictorio, porque la práctica de los doctrineros no era coincidente con la doctrina proclamada. ${ }^{10}$

En realidad, España trató de impedir "por todos los medios que las ideas y prácticas de las reformas

${ }^{9}$ No es posible saber qué versión de la Biblia estuvo al alcance de Guamán Poma. Pero, probablemente haya sido la Vulgata que aunque prohibida a los indoctos, era la oficial y la que al menos el clero podía tener acceso.

${ }^{10}$ La obra de Guamán Poma la tituló: Primer y Nueva Crónica y Buen Gobierno. Para un estudio del impacto bíblico conquistador en el Perú, ver Samuel Escobar, "Impacto y asimilación de la visión bíblica de la historia durante la conquista española: El caso de Guamán Poma de Ayala", Theologika 2:1 (1985) 90-114. Para un estudio de la misma obra de Guamán, ver Guillermo Ludeña de la Vega, La obra del cronista indio Felipe Guamán Poma de Ayala - Vol. I (Lima: n.e., 1975); también Abraham Padilla Bendezú, Guamán Poma, el indio cronista dibujante (México: Fondo de Cultura Económica, 1979). 
luterana, calvinista y anabaptista, entre otras, llegaran a la Nueva España" ${ }^{11}$ Para esto se estableció el tribunal de la Inquisición en Lima en 1568, en México en 1571 y en Cartagena de las Indias en 1610. Pero, incluso ya en 1537 el papa Pablo III había decretado la prohibición de la entrada de los herejes a las Indias.

Tras el Concilio de Trento (1545-1563), ya consolidada la Contrarreforma, se acentuó un "cordón preventivo" en torno a las nuevas colonias de España. Así se buscaba mantener al Nuevo Mundo exento de la contaminación herética que había avasallado Europa, con el consiguiente debilitamiento de cristianismo romano. De hecho uno de los objetivos de la Inquisición, tanto en España como en sus colonias americanas, fue el impedir que la Biblia llegara a la población en su propia lengua.

Cuando en 1543 apareció la primera versión del Nuevo Testamento en castellano, traducido del griego por Francisco de Encinas, apenas dos años antes de que se iniciara el Concilio de Trento, hacía ya 21 años que Martín Lutero había dado al pueblo alemán su versión bíblica y William Tyndale había hecho lo propio al inglés. En tanto que Bruccioli y Pierre Olivetan pusieron sus versiones italiana y francesa respectivamente diez y ocho años antes al alcance de sus pueblos.

Enrique Fernández refiere que en la actualidad, existen poquísimas copias del Nuevo Testamento de Encinas, debido a que "apenas sacada a la luz, sus ejemplares fueron prohibidos, recogidos y secuestrados

${ }^{11}$ Carlos Martínez-García, "La Biblia en la Nueva España”, Boletín Teológico 24:47-48 (1992) 197. 
por las autoridades eclesiásticas y civiles", pese a que Encinas dedicó su obra al emperador Carlos V. ${ }^{12}$

La Inquisición española fue muy efectiva con la literatura reformadora que consideró herética y dentro de la cual la Biblia estaba catalogada como tal. Apenas a cinco años de iniciada la reforma, los inquisidores decomisaron en Sevilla 450 ejemplares de la Biblia impresa en el extranjero. ${ }^{13}$ Cuando en 1551 el inquisidor general Valdez amplió la lista de autores prohibidos, se decretaron adicionalmente reglas especiales para la impresión y circulación de la Biblia y literatura hebrea y árabe.

Entre los años 1558 y 1559 la intolerancia inquisitorial se acrecentó, buscando eliminar las ideas que no toleraba, y de esto Kamen nos señala:

Los libros se dividían en secciones según su lenguaje y se prohibían si caían en las siguientes categorías: todos los libros escritos por heresiarcas; todos los libros religiosos escritos por los condenados por la Inquisición; todos los libros sobre judíos y moros con tendencia anticatólica; todas las traducciones heréticas de la Biblia; todas las traducciones de la Biblia a lenguas vernáculas,

${ }^{12}$ Enrique Hernández y Fernández, Las biblias castellanas del exilio. Historia de las biblias castellanas del siglo XVI (Miami: Editorial Caribe, 1976), 32,33 .

${ }^{13}$ Para un estudio de cómo la Inquisición eliminó a la Reforma en España, y de manera especial en Sevilla, entre los años 1530 a 1560, véase Mario Veloso, "La Reforma en Sevilla: 1530-1560", publicada en Theologika 2:1 (1985) 62-74; Idem, 3:1 (1988) 48-71; Idem, 3:2 (1988) 184-203; Idem, 5:1 (1990) 130-151; Idem, 5:2 (1990) 278-305; 6:2 (1991) 314-352; Idem, 7:1 (1992) 80-108; Idem, 7:2 (1992) 194-221. El impacto producido en la sociedad española por estos reformadores es invalorable. Incluso el mismo emperador Carlos $\mathrm{V}$ respetó, admiró y estimó grandemente las obras y doctrina del doctor Constantino Ponce de la Fuente. 
aunque hubieran sido traducidas por católicos; todos los devocionarios en lengua vernácula; todas las obras de controversias entre católicos y herejes; todos los libros sobre magia; todos los versos que utilizaran citas de las Escrituras 'en sentido profano'; todos los libros impresos en 1515 sin especificar el autor y el editor; todos los libros anticatólicos, todos los libros con cuadros e imágenes irrespetuosos con la religión. ${ }^{14}$

El celo inquisidor español llevó a los traductores de la Biblia a publicar sus obras fuera de España “donde la Inquisición trabajaba con mano de acero y sin contemplaciones, y no dejaba a judíos ni protestantes más opción que la hoguera o el destierro". ${ }^{15}$ Así, diez años después del Nuevo Testamento de Encinas apareció la Biblia de Ferrara, publicada en Italia. Igualmente el Nuevo Testamento de Juan Pérez de Pineda fue impreso en Ginebra. Luego la inigualable "Biblia del Oso"16 hecha por el ex monje de la orden de San Jerónimo, Casiodoro de Reina, tuvo que ser impresa en Basilea en 1569, desafiado las prohibiciones de Valladolid (1559) y del Concilio de Trento (1563), tras huir del Monasterio de

${ }^{14}$ Henry Kamen, La inquisición española (Grijalbo: CNCA, 1990) 114115. La cursiva es para énfasis.

${ }^{15}$ Clemente Ricci, "La Biblia de Ferrara", Publicaciones del Instituto de Investigaciones Históricas - Facultad de Filosofía y Letras, Buenos Aires, 35 (1926) 22, citado por Fernández y Hernández, Las biblias castellanas del exilio, 59. Los traductores de esta Biblia fueron los judíos Abraham Usque y Yom Tob Atías.

${ }^{16} \mathrm{La}$ obra de Casiodoro de Reina es conocida como "La Biblia del Oso" debido a que en medio de la portada, debajo del título, aparece la estampa de un árbol hendido por un mazo colgado de una rama del mismo árbol y en la hendidura se ve un enjambre de abejas de cuyo panal un oso en pie lame su miel, además, en un libro abierto casi al pie del tronco se lee "[la] palabra ... Jehová". 
San Isidoro, Sevilla y buscar exilio en Ginebra, Londres, el castillo de Bergerac, Basilea, Estrasburgo, Amberes y finalmente Francfort cuyo municipio le otorgó la ciudadanía. Esta Biblia es considerada como uno de los pilares de la lengua española del gran siglo XVI y hecha por el "príncipe de los traductores de la Biblia a la lengua castellana". ${ }^{17}$

La publicación de esta Biblia no estuvo libre de peripecias y grandes contratiempos, pues Reina tuvo que estar constantemente huyendo de cada ciudad y país debido al vaivén político de los gobernantes o la muerte de algunos de sus protectores. Tal era la furia inquisidora contra Reina que, en España, fue quemado en efigie varias veces y el mismo rey español Felipe II puso, precio a la cabeza de Casiodoro de Reina en 1564, ofreciendo grandes sumas de dinero al que lograra apresarlo. Finalmente, en agosto de 1569, Reina envía a sus amigos de Estrasburgo en cuatro grandes toneles 900 ejemplares de su preciada Biblia pidiéndoles que ellos dispusieran de los ejemplares según habían acordado, lo que al parecer habían sido introducidos todos en su querida España, por la vía de Flandes. ${ }^{18}$ ¿Cuántas de ellas llegaron al Nuevo Mundo y específicamente al Perú? No es posible responder a esta interrogante.

${ }^{17}$ P. N. Tablante Garrido, "Príncipe de los traductores castellanos", La Biblia en América Latina, 44:708.

${ }^{18}$ Tal es la sospecha expresada por Menéndez Pelayo. Ver Marcelino Menéndez y Pelayo, Historia de los heterodoxos españoles, 8 vols. (Santander: Consejo Superior de Investigaciones Científicas, 1947) Vol. 4, libro 4, cap. 10, 140. Esta edición fue hecha en un tiraje de 1100 ejemplares de los cuales 200 quedaron en Ginebra con el impresor y con Casiodoro, la mayoría de las cuales fue como pago de la deuda de impresión, según testimonio del mismo Reina. 
En realidad, el estricto control asumido por España de las ideas vinculadas con la Reforma y, de modo especial, con el mensaje bíblico impidió al pueblo español acceder a la Escritura en sú idioma. Además, al impedir la Contrarreforma la circulación de la Biblia, estancó el desarrollo de una mentalidad abierta y capaz de adecuarse a los cambios que se presentaron como oportunidad en el mundo a partir del descubrimiento de América.

Pero, todo esto también afectó ostensiblemente al mundo hispano-americano de entonces. Se puede pensar que la parte más saltante de la Inquisición fue la atrocidad de los autos de fe con que se castigaba a los considerados como herejes. Sin embargo, sin ignorar ese aspecto, es necesario considerar igualmente la tarea no menos denigrante de la confiscación de la literatura buscando evitar la propagación delas ideas dela Reforma. Las diócesis episcopales en sus concilios decretaron la prohibición de sermones, epístolas, evangelios y otras porciones de la Biblia traducidos a lenguas indígenas y que se destinaran al uso de los feligreses.

Si bien es cierto que esto suscitó la protesta de algunos clérigos que sentían la seriedad de su misión evangelizadora, puesto que ellos no concebían una catequesis efectiva sin un material bíblico y menos sin el acceso directo a las Escrituras en el idioma propio, la disposición inquisitorial siguió adelante. Así el modelo imperante privó a los americanos y a otros sectores de la población novohispana del acceso a la Biblia.

En realidad uno tiene que admirar a esos clérigos sinceros que buscaron por todos los medios posibles comunicar el mensaje evangélico a quienes debían hacerlo conocido. Estando prohibidos de hacer uso de la 
Escritura misma recurrieron al empleo de las artes para sembrar la semilla de la verdad bíblica; pero, cuando las autoridades inquisitoriales percibían el ingenio de ellos, incluso esas actividades les fueron prohibidas aduciendo que ellas eran impropias o peligrosas para la población, especialmente nativa.

Así, hacia 1575 y en plena efervescencia tridentina fray Luis de León publicó su Nombres de Cristo y Cantares y otras obras suyas las cuales circulaban en el Virreinato del Perú. Sin embargo, las obras del buen fraile fueron vistas como peligrosas por presentar pasajes de la Biblia en la lengua del pueblo de modo que éstas fueron buscadas, confiscadas y enviadas a las llamas de la hoguera inquisitorial. ${ }^{19}$ Cuando el Tercer Concilio Limense (1582-1583), propició el Catecismo de Santo Toribio, que fue una obra trilingüe - castellano, quechua y aymará - lo hizo con cautela y fue un milagro que no fuera a parar a la hoguera. Además, bajo ese mismo "amparo" fueron apareciendo otros libros como los leccionarios de Oré, hacia 1607, en los cuales sea en aymará o quechua aparecían algunos pasajes bíblicos los que eran usados en su tarea pastoral.

Hacia 1588 el jesuita José Acosta insistía que era necesario tener catecismos en quechua y aymará y su protesta era determinante: "Hay algo que a mí me ha parecido casi monstruoso. Entre tantos miles de indios a los que damos el nombre de cristianos, es muy raro que haya uno que conozca a Cristo".

${ }^{19}$ Luis A. Eguiguren, Diccionario histórico cronológico de la Real y Pontificia Universidad de San Marcos y sus Colegios (Lima: Imprenta Torres Aguirre, 1940), 1:710 
Sin embargo, los bocetos de Guaman Poma de Ayala, a comienzos de siglo XVII, para amenizar su Nueva crónica y buen gobierno expresan el entendimiento de algunas verdades bíblicas expresadas en una versión popular propia que es resaltada a lo menos en cuatro de sus dibujos ilustrando la Trinidad, la creación, el nacimiento y la redención.

Bertorio hace referencia a la tarea de los jesuitas de Juli que tradujeron al aymará pasajes de los evangelios y las epístolas. ${ }^{20}$ Por otro lado, Francisco de Ávila en 1648 en su Tratado de los Evangelios vertió al quechua pasajes de los Evangelios exponiéndolos en sermones contra la idolatría. Igualmente en el mismo año Juan Roxo Mexía y Ocón, un profesor de quechua de la Universidad de San Marcos, refiere en una gramática quechua que publicara en 1648, que era su gran anhelo realizar una traducción literal de los Evangelios. ${ }^{21}$ Del mismo modo, hacia 1691, otro profesor de quechua en la Universidad del Cusco, don Estevan Sánchez de Melgar, menciona igualmente su deseo de publicar una traducción parafraseada al quechua de pasajes de los Evangelios. ${ }^{22}$

${ }^{20}$ Ludovic Bertorio, Libro de la vida y milagros de nuestro Señor Iesu Christo (Juli: Francisco de Canto, 1612).

${ }^{21}$ Juan Roxo Mejía y Ocón, Arte de la lengua general de los indios del Perú (Lima: Jorge López Herrera, 1648). Citado en Mitchel, La Biblia en la Historia del Perú, 13-14.

${ }^{22}$ Estevan Sánchez de Melgar, Arte de la lengua general del Inga llamada Qqechhua (Lima: Diego de Lyra, 1691). Es posible que no llegara a publicar su soñada obra pero el manuscrito de su obra está en el Archivo Nacional de Colombia en Bogotá: Lucema ynidica y traducción paraphrastica de todos los Evangelios que canta la Yglesia, según el sentir de los santos Padres, sagrados expositores, y versiones sacras. Citado en Mitchel, La Biblia, 14. 
En realidad, pese a las restricciones inquisitoriales, a la prohibición del uso de la Escritura y a su traducción y a las tribulaciones propias del momento en la aventura de la edición de la Biblia, los escasos datos del momento permiten señalar que entre 1590 y 1690 hubo en el Virreinato del Perú una incesante actividad traductora bíblica a las lenguas autóctonas principales del Perú que, de una manera u otra, contribuyeron a la comunicación del mensaje evangélico a la población peruana.

Pero fue el canto el que también sirvió como vehículo para la presentación de la Biblia y su mensaje. Esto ha sido demostrado en la obra de Jorge Lira, quien publicó una colección de himnos cantados por el pueblo andino en los siglos de la conquista, ${ }^{23}$ los cuales muestran la forma cómo expresaban los fieles andinos la doctrina enseñada por las órdenes de los franciscanos, dominicos, mercedarios, agustinos y jesuitas y, sobre todo, que en el desarrollo de la evangelización la música fue un asunto de importancia en el currículo catequista. ${ }^{24}$ Ya en las postrimerías del mismo siglo, en el año 1599, en Juli había un coro de 400 voces con cantores nativos en el templo mayor que entonaban pasajes del evangelio. Igualmente en el mismo Juli se imprimieron las primeras obras bilingües en aimará y español, dedicados a defender la doctrina cristiana.

${ }^{23}$ Jorge Lira, Himnos sagrados de los Andes - Vols. I-II (Buenos Aires: Ricordi Americana, 1960). Estos himnos fueron coleccionados por el autor en las diferentes parroquias del Cusco donde ejerció su trabajo. El primer volumen contiene esencialmente himnos a Jesús, en tanto que el segundo a la virgen María.

${ }^{24}$ Bill Mitchell, "Text and Context in Southern Peru: Himnos Sagrados de los Andes", The Bible Translator 55:3 (July 2004) 376. 
Algo notable, es la manera cómo el mismo Guamán Poma se encarga de dar alguna vislumbre del modo cómo los atribulados nativos peruanos captaron el mensaje bíblico al expresar su clamor ante el trato injusto al que eran sometidos en su diario vivir y ponen su reclamo justo en consonancia con el clamor profético escuchado de algún modo en las prédicas de sus doctrineros:

Todo el mundo den bozes y mucho más bosotros, yndios, yndias. Dad bozes con los profetas, como dijo el profeta: Señor, ¿hasta quándo daré bozes y no me oirás? Señor ¿hasta quándo clamaré y no me rresponderás? Con ellos juntamente decid a bozes llorando, gimiendo con tu corazón y ánima, boca y lengua y los ojos no sese de llorar con los profetas que os ayudará. Y todo el mundo me responda 'Amén. Jesús'. Y bosotros ermanos y ermanas de este reyno, yndios, yndias me rrespondedme 'Amén. Jesús.'.25

La exposición de la Biblia a los peruanos, aunque en forma escasa, también estuvo presente en los colegios a los cuales asistían los hijos de la nobleza privilegiada y sin duda allí dio sus frutos en forma inesperada en el espíritu y anhelo de independencia.

En tal sentido, es casi desconocido que la gesta libertaria dirigida por el valeroso prócer peruano Juan Santos Atahualpa tuvo su inspiración en el mensaje de libertad proclamado por el evangelio al sublevarse en 1742 contra la tiranía esclavizante en la selva peruana central. Este caudillo libertario era un cristiano instruido y fundó en la Biblia su anhelo por la libertad

${ }^{25}$ Guaman Poma, Nueva crónica y buen gobierno, 850. 
de su pueblo. Él incluso hablaba latín y llegó a leer la Vulgata de modo directo. En su proyecto libertador fue apoyado por las etnias asentadas en las riberas del Tambo, Perené y Pichis las que se sublevaron contra los frailes de las misiones franciscanas. Inició su acción en Quisopango y el núcleo de sus actividades fue en el cerro de la Sal, Quimiri y el Gran Pajonal, llegando hasta Chanchamayo y Pozuzo. Inclusive Tarma y Jauja temieron su acción y dos virreyes no lograron subyugarlo. En los 13 años de su rebelión las misiones católicas de Chanchamayo, Perené, Huancabamba, Gran Pajonal y Alto Ucayali fueron asoladas. Su levantamiento no culminó positivamente debido a que él desapareció tan misteriosamente como apareció, pero nunca fue derrotado.

Igualmente, pocos conocen que el movimiento libertario liderado por el prócer peruano José Gabriel Condorcanqui, curaca de Pampamarca, Surinama y Tungasuca, fue motivado principalmente por los principios de libertad revelados en el evangelio de Jesucristo ${ }^{26}$ que él conoció en la Biblia y que llegaron a cautivar el corazón de este valiente peruano que se atrevió a desafiar el oscurantismo intolerante de sus días. ${ }^{27}$ Pero, en ese lejano 1780 ¿qué se podía esperar de una sociedad

${ }^{26}$ Estuardo McIntosh B., "La Biblia en la historia del Perú", conferencia presentada en el Seminario de Ciencia Bíblica, La palabra de Fe y Esperanza, Lima, junio de 1996.

${ }^{27}$ Estando ya su movimiento en marcha, Túpac Amaru escribió a un amigo suyo: “. . . aquí estoy para que me castiguen, sólo a fin de que otros queden con vida y yo sólo con el castigo, pero ahí está Dios, quien con su sangre misericordiosa me ayudará y remunerará mi buen deseo ..." Manuel Zunutelli, et al., Compendio histórico del Perú (Lima: Editorial Milla Batres, 1993), 4:173. 
que era dirigida y alentada por una autoridad inquisidora, dominadora y opresora que no aceptaba ni mucho menos quería entender el mensaje bíblico que establece que el derecho de obedecer a Dios antes que a los hombres es inalienable? De modo que, Túpac Amaru II pasó a la historia como un mero rebelde al status quo político implantado en el Perú por el invasor, y no como un creyente en la verdad evangélica de la igualdad de todos los hombres y la libertad de adorar sólo al crucificado como lo establece la Palabra revelada. Así pues, en la plaza mayor del Cusco, el 18 de mayo de 1781, lamentablemente la iglesia de esos días presidió, bendijo y absolvió la ejecución no sólo de un patriota que se rebeló contra el rey usurpador, sino de un hereje que atacó la religión del régimen. Evidentemente, todos sus verdugos mismos nunca fueron movidos por el mensaje liberador y transformador de la Biblia.

Apenas cuatro años después de Túpac Amaru, el huanuqueño Gabriel de Aguilar y el arequipeño Manuel Ubalde, inspirados también en el mismo mensaje bíblico, vuelven a buscar la libertad del Perú y también pagaron con su vida tal anhelo, pues corrieron la misma suerte de Túpac Amaru en la misma plaza principal de Cusco el 5 de diciembre de 1805.

En realidad fue recién el siglo XIX el momento cuando la Biblia llegó nuevamente al Perú y esta vez coincidiendo con su grito final de independencia. Es decir, esta vez ella llegó ligada a hombres que sabían el valor de su mensaje, pero, al mismo tiempo aún existía en el ambiente un espíritu contrario a la Biblia y su mensaje. Después que el general don José de San Martín proclamó la independencia el 28 de julio de 1821, él mismo invitó al escocés Diego Thomson para establecer el sistema 
lancasteriano como parte del sistema educacional del Perú. ${ }^{28}$ Él llegó a Lima el 28 de junio de 1822 y de inmediato se expidió el 6 de julio de 1822 un decreto que establecía la primera escuela bajo el sistema con la dirección de Thomson. ${ }^{29}$ La alegría de ambos líderes fue la instalación del sistema el 19 de setiembre del mismo año con la presencia de San Martín quien poco después se retiró del Perú de modo definitivo. Tanto Lancaster como Thomson empleaban la Biblia como texto y, de esta manera, al mismo tiempo divulgaban el mensaje bíblico entre muchos estudiantes. ${ }^{30}$

Sin embargo, una de las alegrías más grandes que Thomson tuvo, en Lima, fue la distribución de biblias de la misma esquina de la sede del Tribunal de la Inquisición en la plaza del Congreso, hoy la avenida Abancay. Cupo a Thomson ser el primero en vender biblias libremente en el Perú en un tiempo cuando el protestantismo era condenado y tenido como herejía. Sus cartas rebosan de alborozo al mencionar su éxito y sobre todo su venta de biblias al costado del edificio de la Inquisición. Él escribió: "Ahora la Biblia es vendida públicamente a corta distancia del lugar donde una vez estuvo la sede de la temible Inquisición. ¡Que desaparezca toda injusticia de la tierra! ¡Que el conocimiento y el amor de Dios

${ }^{28} J u a n$ C. Vareto, Diego Thomson: Apóstol de la Instrucción Pública e Iniciador de la Obra Evangélica en la América Latina (Buenos Aires: Imprenta Evangélica, 1918), 44.

${ }^{29}$ Ésta es la razón por la cual en el Perú se celebra el día del maestro el 6 de julio.

${ }^{30}$ Guillermo Cabrera Leiva, "El sistema Lancaster de América", Diario Las Américas, martes 9 de abril de 1985, 4-A, 15-A. 
abunden por doquiera!" ${ }^{31}$ El anhelo de Thomson era de alcanzar al mayor número posible de personas con el mensaje bíblico pues expresaba en su informe a las Sociedades Bíblicas: "roguemos al cielo, que empiecen a recibir estos infelices gentiles alguna educación; que se ponga en sus manos la Santa Escritura; y que baje a ellos el espíritu de Dios". ${ }^{32}$

De las dos escuelas que se abrieron en Lima con la orden del Libertador San Martín, la primera tuvo un alumnado de 230 y la otra de 80 y en ambas se usaba como principal libro de escuela el Nuevo Testamento editado por la Sociedad Bíblica de Londres. Thomson incluso detalla la metodología utilizada en las aulas con la lectura bíblica, pues refiere que:

Este libro sagrado leían los niños de las escuelas superiores, y 'se les hacía preguntas sobre su contenido. Llevábanle también a casa, y allí aprendían algunos pasajes de memoria, los cuales se recitaban después en la escuela, confieriéndose premios a los que sobresalían en la actitud e inteligencia de ellos. Manejábanse asimismo libros impresos que contenían pasajes escogidos de las Escrituras, y algunos padres mandaban a pedir ejemplares de ellos; extendiéndose de este modo el conocimiento de la Palabra de Dios, y acaso también la veneración y obediencia de los divinos oráculos. ${ }^{33}$

${ }^{31}$ Arnoldo Canclini, Diego Thomson. Apóstol de la enseñanza y distribución de la Biblia en América Latina y España (Buenos Aires: Compañía Impresora Argentina, 1987), 79.

${ }^{32}$ William Mitchell, "Informe de Diego Thomson a la Comisión de la Sociedad de Escuelas Británicas y Extranjeras", Textos para la Acción 5:9 (diciembre 1997) 72.

${ }^{33}$ Ibíd., 71. Notablemente, la primera escuela fue establecida en un 
Thomson, de inmediato, se percató en la proporción de población autóctona peruana que hablaba quechua y aymará y se avocó a la publicación del Nuevo Testamento para esos pueblos. Así logró reunir a cuatro personas para iniciar un proyecto de traducción del Nuevo Testamento al quechua y la tarea se completó en 1824. Sin embargo, los momentos turbulentos de la independencia le obligaron a refugiarse en Trujillo dejando el manuscrito con un conocido suyo de cuyas manos desapareció. Thomson no se dio por vencido e inició un nuevo proyecto de traducción del Nuevo Testamento al aymará, esta vez en Londres. Por suerte esta vez contó con la ayuda de un ex sacerdote boliviano, Vicente Pazos Kanki, que había sido profesor en la Universidad del Cusco. Su tarea la completó en 1826, pero el mismo profesor publicó el evangelio de Lucas y los Salmos en quechua en 1828 y 1930 respectivamente. Así, cupo a este profesor hacer la primera traducción a un idioma

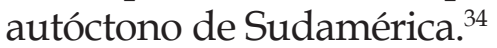

Por razones políticas conocidas el General San Martín se alejó del Perú, pero don Simón Bolívar estuvo igualmente convencido de que el método lancasteriano "era elúnico método para promover pronta y eficazmente la instrucción pública", ${ }^{35}$ por lo tanto, concedió su pleno apoyo a Thomson en el establecimiento del sistema de Lancaster en el Perú. ${ }^{36}$

convento de los dominicanos.

${ }^{34}$ William Mitchel, "Diego Thomson: Precursor de la traducción bíblica en la época moderna", Textos para la acción 5:9 (diciembre 1997) 58-59.

${ }^{35}$ Armando Rojas, Ideas educativas de Simón Bolívar (Barcelona: Plaza \& Janes, S.A., 1972), 59.

${ }^{36}$ Félix Denegri Luna, Obra Gubernativa y Epistolario de Simón Bolívar 
Pero, en esos años, aún no eran tiempos de libertad y bonanza, pues la intolerancia religiosa arbitró los mecanismos para tratar de desterrar la libertad y la Junta Gubernativa aprobó, el 19 de diciembre de 1822, un decreto donde se establecía que cualquier escrito considerado como contrario a la religión, moral y/o decencia podría ser perseguido por la acción popular y por el mismo Estado. ${ }^{37}$

La efectividad de este decreto fue exigida casi de inmediato, ya que algunas semanas después el presbítero José Mateo Aguilar envió un recurso al Congreso tocante a libros prohibidos, donde exigía que se tomasen medidas oportunas con respecto a la introducción, venta y circulación de obras contrarias a la religión y a la "indefinida libertad" de la que gozaba la prensa. El eclesiástico Aguilar se refería, entre otras obras, a las biblias que Diego Thomson, agente de la Sociedad Bíblica Extranjera y Británica, había vendido en Lima pese a que las biblias eran de la versión católica de Scío de San Miguel. Aguilar exigía la aplicación de la ley, con el propósito de:

. . . desterrar de nuestro suelo hasta el último miasma de tantos libros heréticos, y blasfemos, y sediciosos, y que llevan consigo fermentos de muerte capaces de aniquilar la más bien organizada y robusta constitución del Estado. ${ }^{38}$

- Colección Documental de la Independencia del Perú (Lima: Editorial Jurídica, 1976), tomo XIV, 3:385.

${ }^{37}$ Así lo establece el decreto aprobado por el Congreso el 18 de diciembre de 1822, sancionado por el Ejecutivo al día siguiente. Archivo Arzobispal de Lima, siglo XIX, legajo s.n., año 1822.

${ }^{38}$ Pilar García Jordán, Iglesia y poder en el Perú contemporáneo 1821- 
En este ambiente contrario a la Biblia llegó al Perú en 1880 con Francisco Penzotti, agente de las Sociedades Bíblicas y pudo iniciar en 1888 la primera Agencia Bíblica del Pacífico en el Callao. Sin embargo, desde un comienzo tuvo dificultades en sus labores y predicación, por lo cual fue apresado en Arequipa y luego recluido en los calabozos del Real Felipe en el Callao el 26 de julio de 1890, por violar el artículo $4^{\circ}$ de la Constitución. Sin embargo, su causa fue tomada por todos los liberales, y cuando fue liberado de sus prisiones, el 28 de marzo de 1891, la causa libertaria evangélica, y con ello la causa bíblica tenía un nuevo capítulo ganado en el Perú.

Hacia esta misma década se realizó una nueva traducción del Nuevo Testamento al quechua por doña Clorinda Matto de Turner, quien fue una influyente política cusqueña, cuya versión fue impresa en 1901 en Buenos Aires. Esta edición fue distribuida ampliamente en Perú, Ecuador y Bolivia, siendo la convicción de la misma traductora que su obra respondería "al propósito de que la palabra divina sea conocida en todas las regiones sudamericanas que todavía conservan ese idioma tan rico y tan expresivo; y con el Evangelio irá la luz y el consuelo a los hogares indígenas". ${ }^{39}$

Las condiciones políticas de la última década del siglo XIX así como las dos primeras del siguiente con la participación decidida del Partido Liberal propiciaron,

1919 - Archivos de Historia Andina 12 (Cusco: Centro de estudios regionales Andinos "Bartolomé de las Casas", s/f), 53. La cursiva es para énfasis.

${ }^{39}$ Apunchis Jesé-Cristoc Evangelion San Lucaspa Qquelkascan, 2da. Ed. (Lima: Imprenta El Progreso Editorial, 1912), 4. Citado en Mitchel, La Biblia en la Historia del Perú, 29. 
de algún modo, el terreno apropiado para la apertura de la tolerancia religiosa en el Perú. Esta coyuntura político social allanó, en cierta medida, las dificultades para que las iglesias protestantes comenzaran a establecerse en suelo peruano fundando instituciones educativas. Los presbiterianos, la Unión Misionera para Regiones Lejanas, los Adventistas del Séptimo Día así como otras misiones figuran en este quehacer evangélico en el Perú. ${ }^{40}$ No obstante, como lo señala Klaiber, de todas ellas los dos grupos que más aprovecharon la coyuntura liberacionista de las primeras décadas del siglo XX fueron los metodistas y los adventistas. ${ }^{41}$

Escobar al considerar esta realidad histórica tras afirmar primero que "el evangelio que vino a América Latina con el protestantismo, vino como fuerza liberadora porque trajo la fuerza del mensaje bíblico" ${ }^{42}$ procede luego a referir a sus lectores la experiencia de Manuel Zúñiga Camacho y los esposos misioneros Fernando y Ana Stahl en la escuela de Platería, Puno. ${ }^{43}$ Esta escuela fue primero iniciativa de Manuel Zúñiga quien comenzó una escuelita en 1902 en su anhelo de educar a sus conciudadanos y, para el aprendizaje de

${ }^{40}$ Para un estudio de la actividad educativa de la Iglesia Adventista en el Perú, ver Merling Alomía, Breve Historia de la educación Adventista en el Perú - 1898-1996 (Lima: Ediciones Theologika, 1996).

${ }^{41}$ Jeffrey Klaiber, La iglesia en el Perú. Su historia social desde su independencia (Lima: Fondo Editorial de la Universidad Pontificia del Perú, 1988), 27.

${ }^{42}$ Samuel Escobar, La fe evangélica y las teologías de liberación (El Paso: Casa Bautista de Publicaciones, 1987), 18-20.

${ }^{43}$ Ibíd., 118-120. 
lectura, empleaba sólo la Biblia, por lo cual desde un comienzo fue obstaculizado tremendamente por el clero, autoridades y hacendados de Puno. Con la ayuda recibida por la Iglesia Adventista del Séptimo Día la escuelita se trasladó a Platería, ya bajo la dirección de los esposos Stahl. ${ }^{44}$

Sin embargo, un ataque a esta Escuela-Misión el 3 de marzo de 1913, dirigida por el mismo obispo de Puno, monseñor Víctor Ampuero y algunas autoridades y jueces de Chucuito, fue determinante para que el estudio de la Biblia en el Altiplano del Perú y el país en general se acentuara pues, contra todo pronóstico, lejos de ser eliminada la escuela, este ataque resultó ser el detonante necesitado para la culminación de la anhelada libertad de cultos en el Perú lograda en el Congreso de la República el 15 de octubre de 1915 con la modificación del artículo IV de su Constitución. ${ }^{45}$ Kessler señala que este hecho constituyó un factor de suma importancia para que posteriormente "la obra evangélica pudiese desarrollarse en un clima de mayor libertad". ${ }^{46}$

Conviene sí señalar que un hito importantísimo de la Biblia en la historia del Perú durante el siglo XX fueron

${ }^{44}$ Merling Alomía, “Un importante centenario en la historia de las misiones", Theologika 13:2 (1998) 256-329.

${ }^{45}$ Para un detalle del ataque a la Escuela-Misión de Platería y sus repercusiones, véase Merling Alomía, “Un importante centenario en la historia de las misiones", Theologika 13:2 (1998) 259-329. También Herbert Money, La Libertad religiosa en el Perú. La Reforma del Artículo $4^{\circ}$ de la Constitución del Perú, 1915 (Lima: Concilio Nacional Evangélico del Perú, 1965), 35-38.

${ }^{46}$ Juan B. A. Kessler, Historia de la evangelización en el Perú (Lima: Ediciones Puma), 231. 
las actividades del Instituto Lingüístico de Verano ${ }^{47}$ que a partir del año 1946, ha venido traduciendo importantes porciones de la Biblia a varias lenguas nativas peruanas, especialmente en la Amazonia. De igual modo, el mismo año 1946 se funda la Sociedad Bíblica Peruana, ${ }^{48}$ la cual sólo en el año pasado ha logrado el admirable récord de distribución de 380000 ejemplares de la Biblia en el país y unos cinco millones sólo en los últimos veinte años, lo que demuestra la demanda creciente de biblias de estos días. Las actividades de ambas instituciones son sin duda valiosísimas para la difusión de las Escrituras en nuestro país. Por otro lado, notablemente también, a partir del II Concilio Vaticano, han surgido algunas instituciones católicas que se han puesto como tarea la difusión de la Biblia en toda la América Latina y, por consiguiente, en el Perú.

Al revisar la historia peruana, uno puede percibir que la Biblia estuvo presente en el quehacer de la sociedad peruana, tal como se evidencia en el claustro, la liturgia, el teatro, el arte, la cátedra, la literatura, el arte, la ciudad, el campo, pero, también en la devoción familiar y personal. Su impacto en el ámbito religioso,

${ }^{47} \mathrm{El}$ Instituto Lingüístico de Verano fue fundado por W. Cameron Townsend, como una institución privada dedicada a la investigación etnolingüística, la alfabetización y eminentemente a la traducción de la Biblia a lenguas aborígenes. En la actualidad es la entidad evangélica misionera más grande en el mundo pues, unida a su sociedad Wycliffe Bible Translators Internacional, emplea a un contingente que supera las 5000 personas.

${ }^{48}$ Antes de esa fecha en el Perú funcionaban agencias de la Sociedad Bíblica Americana y de la Sociedad Bíblica Británica y Extranjera. 
cultural y social, pese a su prohibición, es innegable y sobre todo positivo y saludable.

Un hecho curioso relacionado con la Biblia ocurrió durante la visita de don Juan Pablo II al Cusco, el año 1985. El 3 de febrero, tras oficiar la Liturgia de la Palabra en la fortaleza de Sacsahuamán, se le entregó una carta abierta de varios movimientos indígenas. Allí le devolvieron la Biblia, pues le decían que, "en cinco siglos no nos ha dado amor, la paz y la justicia". Además, le pidieron que la entregase a sus opresores en el primer mundo, aseverando que ellos la necesitaban más que el pueblo andino. ${ }^{49}$

La trayectoria de la Biblia a lo largo de la historia del Perú ha sido azarosa, perseguida, persistente, valiosa, pero triunfante y sobre todo fructífera. A lo largo del transitar la influencia de la Biblia ha transformado la historia de los lugares donde ha llegado y las vidas de quienes han aceptado su mensaje y sigue haciéndolo hoy. Su efecto ha cambiado millones de vidas. Los libros escritos de los hombres no pueden hacer esto a menos que citen la Biblia.

Hoy el poder del mensaje de la Biblia en las vidas de quienes aceptan su mensaje libertador sigue produciendo ese gran efecto orientador y, sobre todo, transformador maravilloso que cambió a millones tal como ocurrió con la vida de Oswaldo Gonzáles Morales,

${ }^{49}$ Citado por Mitchell, La Bibliaen la historia del Perú,34. Evidentemente los promotores de estos "movimientos indígenas" son movidos por un espíritu contrario al de la Biblia y a la realidad del evangelio manifestada en los pueblos andinos que verdaderamente recibieron el mensaje bíblico, pues los pueblos nativos que aceptaron el mensaje evangélico de la Biblia disfrutan del amor, paz y justicia que da el Salvador de la Biblia. 
más recordado en el ámbito de la delincuencia como Django. ${ }^{50}$

Todavía el que la inspiró nos exhorta a cada uno “Escudriñad la Escrituras, porque en ellas os parece que tenéis la vida eterna y ellas son las que dan testimonio de mí" (Juan 5:39). Esto es tan real como siempre lo fue pues "toda la Escritura es inspirada por Dios y es útil para enseñar, para reargüir, para corregir, para instruir en justicia, a fin de que el hombre a Dios sea perfecto (2 Timoteo 3:16-17pp).

Qué inmejorable bendición es saber que en medio de la incertidumbre de este mundo podemos descansar con absoluta confianza en la Palabra de Dios. A lo largo del destino de la historia humana y contra los inclementes ataques satánicos, Dios ha preservado su bendito libro, la Santa Biblia.

${ }^{50}$ Django fue un notable delincuente cajamarquino que se especializó en el asalto a bancos y ha sido catalogado incluso como "el delincuente más peligroso del Perú". Éste estableció su guarida principal en el Callao, hasta el día cuando cambió sus pistolas por la Biblia. En su récord delictivo figuran el asalto a cerca de 200 bancos y su paso en las prisiones del Frontón, Lurigancho, el Sexto, Castro Castro, La Oroya, Cachiche, etc., habiendo estado de este modo la mitad de su vida recluido en prisión pero, a su vez, se hizo muy conocido por sus fugas de estas cárceles. Cada una de ellas fue muy sonada, siendo la más espectacular de todas la de Lurigancho cuando tuvo en vilo a toda la Guardia Republicana, pues la que estaba en el penal había sido tomada por él, a punta de pistola y dinamita, como rehén y la situación sólo pudo arreglarse cuando se cumplió con la exigencia impuesta por Django de canje de vida por vida (la de Django y sus compinches por la de los policías rehenes) en trato directo con el Ministro de Justicia. De esta manera los amotinados salieron airosos e igualmente la policía sin daño. Finalmente, el mensaje de la Biblia tocó su ser y cambió el rumbo de su vida, pues hoy es un cristiano al servicio del Dios que cambió su vida mediante el poder de la Biblia. Hoy Django sigue visitando las prisiones pero, no más como reo sino llevando el mensaje evangélico de la Biblia que da la auténtica libertad de la esclavitud del pecado. http://www.radioreforma.com/index. php?option=com_emisoras\&Itemid=58. Consultado el 10 de diciembre, 2010. 
La Biblia contiene un relato correcto de nuestros orígenes, asimismo un relato confiable de nuestra salvación y una veraz vislumbre gloriosa de nuestra liberación venidera. Como cristianos, aceptamos la Biblia como el fundamento para todas nuestras creencias, pues de no hacerlo erraríamos del rumbo al cual hemos sido llamados: hijos e hijas de Dios.

Notablemente, en el Perú, aunque en un comienzo durante la conquista y la colonia la Biblia fue muy prohibida y perseguida y, durante los días de la República restringida, no pudo ser extirpada pues hoy su difusión y circulación es amplia, libre y determinante; su influencia ha sido en muchísimos casos transformadora, pues la promesa de Dios es "mi Palabra no volverá vacía" (Isaías 55:11). : 